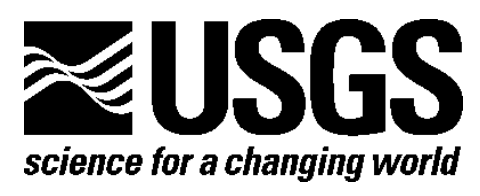

\title{
Publications of the Volcano Hazards Program 2012
}

By Manuel Nathenson

Open-File Report 2014-1147

U.S. Department of the Interior U.S. Geological Survey 


\section{U.S. Department of the Interior \\ SALLY JEWELL, Secretary}

\section{U.S. Geological Survey \\ Suzette M. Kimball, Acting Director}

\section{U.S. Geological Survey, Reston, Virginia: 2014}

For product and ordering information:

World Wide Web: http://www.usgs.gov/pubprod

Telephone: 1-888-ASK-USGS

For more information on the USGS-the Federal source for science about the Earth, its natural and living resources, natural hazards, and the environment:

World Wide Web: http://www.usgs.gov

Telephone: 1-888-ASK-USGS

Suggested citation:

Nathenson, Manuel, 2014, Publications of the Volcano Hazards Program 2012: U.S. Geological Survey Open-File Report 2014-1147, 10 p., http://dx.doi.org/10.3133/ofr20141147.

ISSN (2331-1258) online

Any use of trade, product, or firm names is for descriptive purposes only and does not imply endorsement by the U.S. Government.

Although this report is in the public domain, permission must be secured from the individual copyright owners to reproduce any copyrighted material contained within this report. 


\section{Publications of the Volcano Hazards Program 2012}

By Manuel Nathenson

The Volcano Hazards Program of the U.S. Geological Survey (USGS) is part of the Geologic Hazards Assessments subactivity, as funded by Congressional appropriation. Investigations are carried out by the USGS and with cooperators at the Alaska Division of Geological and Geophysical Surveys, University of Alaska Fairbanks Geophysical Institute, University of Hawaii Manoa and Hilo, University of Utah, and University of Washington Geophysics Program. This report lists publications from all of these institutions.

Only published papers and maps are included here; abstracts presented at scientific meetings are omitted. Publication dates are based on year of issue, with no attempt to assign them to a fiscal year. 


\section{Volcano Hazards Program Publications 2012}

Arciniega-Ceballos, Alejandra, Dawson, Phillip, and Chouet, B.A., 2012, Long period seismic source characterization at Popocatépetl volcano, Mexico: Geophysical Research Letters, v. 39, L20307, doi:10.1029/2012GL053494, 5 p.

Aryal, Arjun, Brooks, B.A., Reid, M.E., Bawden, G.W., and Pawlak, G.R., 2012, Displacement fields from point cloud data-Application of particle imaging velocimetry to landslide geodesy: Journal of Geophysical Research, v. 117, F01029, doi:10.1029/2011JF002161, 15 p.

Bacon, C.R., Grove, Marty, Vazquez, J.A., and Coble, M.A., 2012, The Stanford-U.S. Geological Survey SHRIMP ion microprobe-A tool for micro-scale chemical and isotopic analysis: U.S. Geological Survey Fact Sheet 2012-3067, 4 p. [Also available at http://pubs.usgs.gov/fs/2012/3067/.]

Bacon, C.R., Vazquez, J.A., and Wooden, J.L., 2012, Peninsular terrane basement ages recorded by Paleozoic and Paleoproterozoic zircon in gabbro xenoliths and andesite from Redoubt volcano, Alaska: Geological Society of America Bulletin, v. 124, p. 24-34.

Beachly, M.W., Hooft, E.E.E., Toomey, D.R., and Waite, G.P., 2012, Upper crustal structure of Newberry Volcano from P-wave tomography and finite difference waveform modeling: Journal of Geophysical Research, v. 117, B10311, doi:10.1029/2012JB009458, 17 p.

Behnke, S.A., Thomas, R.J., Krehbiel, P.R., and McNutt, S.R., 2012, Spectacular lightning revealed in 2009 Mount Redoubt eruption: Eos Transactions American Geophysical Union, v. 93, p. 193-194.

Bergfeld, D., Evans, W.C., Lowenstern, J.B., and Hurwitz, S., 2012, Carbon dioxide and hydrogen sulfide degassing and cryptic thermal input to Brimstone Basin,

Yellowstone National Park, Wyoming: Chemical Geology, v. 330-331, p. 233-243.

Blatter, Dawnika, 2012, Obsidian: Singapore, McGraw-Hill Encyclopedia of Science \& Technology, 11th ed., v. 12, p. 281-282.

Bond, A.L., Evans, W.C., and Jones, I.L., 2012, Avian mortality associated with a volcanic gas seep at Kiska Island, Aleutian Islands, Alaska: The Wilson Journal of Ornithology, v. 124, p. 146-151.

Carbone, Daniele, and Poland, M.P., 2012, Gravity fluctuations induced by magma convection at Kīlauea Volcano, Hawai'i: Geology, v. 40, p. 803-806.

Carey, R.J., Manga, Michael, Degruyter, Wim, Swanson, Donald, Houghton, Bruce, Orr, Tim, and Patrick, Matthew, 2012, Externally triggered renewed bubble nucleation in basaltic magma - The 12 October 2008 eruption at Halema'uma'u Overlook vent, Kîlauea, Hawai'i, USA: Journal of Geophysical Research, v. 117, B11202, doi:10.1029/2012JB009496, 10 p.

Chiodini, Giovanni, Caliro, Stefano, Lowenstern, J.B., Evans, W.C., Bergfeld, Deborah, Tassi, Franco, and Tedesco, Dario, 2012, Insights from fumarole gas geochemistry on the origin of hydrothermal fluids on the Yellowstone Plateau: Geochimica et Cosmochimica Acta, v. 89, p. 265-278.

Clor, L.E., McCleskey, R.B., Huebner, M.A., Lowenstern, J.B., Heasler, H.P., Mahony, D.L., Moloney, Tim, and Evans, W.C., 2012, Water chemistry and electrical 
conductivity database for rivers in Yellowstone National Park, Wyoming: U.S. Geological Survey Data Series 632, 18 p., data files. [Available at http://pubs.usgs.gov/ds/632/.]

Clynne, M.A., Robinson, J.E., Nathenson, Manuel, and Muffler, L.J.P., 2012, Volcano hazards assessment for the Lassen region, northern California: U.S. Geological Survey Scientific Investigations Report 2012-5176-A, 47 p., 1 plate, scale 1:200,000. [Also available at http://pubs.usgs.gov/sir/2012/5176/a/.]

Coombs, M.L., and Bacon, C.R., 2012, Using rocks to reveal the inner workings of magma chambers below volcanoes in Alaska's National Parks, in Volcanoes of the Katmai and the Alaska Peninsula: Alaska Park Science, National Park Service, v. 11, no. 1, p. 26-33.

Coombs, M.L., McGimsey, R.G., and Browne, B.L., 2012, Geologic map of Mount Gareloi, Gareloi Island, Alaska: U.S. Geological Survey Scientific Investigations Map 3145, 18 p., 1 sheet, scale: 1:24,000. [Also available at http://pubs.usgs.gov/sim/3145/.]

Dawson, P.B., Benítez, M.C., Lowenstern, J.B., and Chouet, B.A., 2012, Identifying bubble collapse in a hydrothermal system using hidden Markov models: Geophysical Research Letters, v. 39, L01304, doi:10.1029/2011GL049901, 5 p.

De Angelis, Silvio, Fee, David, Haney, Matthew, and Schneider, David, 2012, Detecting hidden volcanic explosions from Mt. Cleveland Volcano, Alaska with infrasound and ground-coupled airwaves: Geophysical Research Letters, v. 39, L21312, doi:10.1029/2012GL053635, 6 p.

Denlinger, R.P., 2012, Effects of catastrophic floods and debris flows on the sediment retention structure, North Fork Toutle River, Washington: U.S. Geological Survey Open-File Report 2011-1317, 25 p. [Available at http://pubs.usgs.gov/of/2011/1317/.]

DeRoin, Nicole, and McNutt, S.R., 2012, Rockfalls at Augustine Volcano, Alaska-The influence of eruption precursors and seasonal factors on occurrence patterns 19972009: Journal of Volcanology and Geothermal Research, v. 211-212, p. 61-75.

DeRoin, Nicole, McNutt, S.R., Sentman, D.D., and Reyes, Celso, 2012, Seismicity of block-and-ash flows occurring during the 2006 eruption of Augustine Volcano, Alaska: Journal of Volcanology and Geothermal Research, v. 213-214, p. 14-26.

Diefenbach, A.K., Crider, J.G., Schilling, S.P., and Dzurisin, Daniel, 2012, Rapid, lowcost photogrammetry to monitor volcanic eruptions-An example from Mount St. Helens, Washington, USA: Bulletin of Volcanology, v. 74, p. 579-587.

Dietterich, H.R., Poland, M.P., Schmidt, D.A., Cashman, K.V., Sherrod, D.R., and Espinosa, A.T., 2012, Tracking lava flow emplacement on the east rift zone of Kīlauea, Hawai' $i$, with synthetic aperture radar coherence: Geochemistry, Geophysics, and Geosystems, v. 13, Q05001, doi:10.1029/2011GC004016, 17 p.

Dixon, J.P., Stihler, S.D., Power, J.A., and Searcy, C.K., 2012, Catalog of earthquake hypocenters at Alaskan Volcanoes-January 1 through December 31, 2011: U.S. Geological Survey Data Series 730, 82 p. [Available at http://pubs.usgs.gov/ds/730/.]

Dzurisin, Daniel, Wicks, C.W, and Poland, M.P., 2012, History of surface displacements at the Yellowstone Caldera, Wyoming, from leveling surveys and InSAR observations, 1923-2008: U.S. Geological Survey Professional Paper 1788, 68 p., CD-ROM. [Also available at http://pubs.usgs.gov/pp/1788/.] 
Eichelberger, John, Marzocchi, Warner, and Papale, Paolo, 2012, Identifying best practices in short-term eruption forecasting: Eos Transactions American Geophysical Union, v. 93, no. 1, p. 5.

Elias, T., and Sutton, A.J., 2012, Sulfur dioxide emission rates from Kīlauea Volcano, Hawai'i, 2007-2010: U.S. Geological Survey Open-File Report 2012-1107, 25 p., data files. [Available at http://pubs.usgs.gov/of/2012/1107/.]

Ely, L.L., Brossy, C.C., House, P.K., Safran, E.B., O’Connor, J.E., Champion, D.E., Fenton, C.R., Bondre, N.R., Orem, C.A., Grant, G.E., Henry, C.D., and Turrin, B.D., 2012, Owyhee River intracanyon lava flows - Does the river give a dam?: Geological Society of America Bulletin, v. 124, p. 1667-1687.

Esposti Ongaro, T., Clarke, A.B., Voight, B., Neri, A., and Widiwijayanti, C., 2012, Multiphase flow dynamics of pyroclastic density currents during the May 18, 1980 lateral blast of Mount St. Helens: Journal of Geophysical Research, v. 117, B06208, doi:10.1029/2011JB009081, 22 p.

Fedele, L., Insinga, D.D., Calvert, A.T., Morra, V., Perrotta, A., and Scarpati, C., 2012, Reply to the comment on the article ${ }^{640} \mathrm{Ar} /{ }^{39} \mathrm{Ar}$ dating of tuff vents in the Campi Flegrei caldera (southern Italy) - Toward a new chronostratigraphic reconstruction of the Holocene volcanic activity" by Isaia et al.: Bulletin of Volcanology, v. 74, p. 297299.

Feldman, Joanne, and Tilling, R.I., 2012, Volcanic eruptions, hazards, and mitigation, chap. 15 of Auerbach, P. S., ed., Wilderness Medicine, 6th ed.: Philadelphia, Pa., Elsevier, Inc., Part Three (Burns, Fire, and Radiation), p. 314-332.

Fierstein, Judy, 2012, The great eruption of 1912, in Volcanoes of Katmai and the Alaska Peninsula: Alaska Park Science, National Park Service, v. 11, no. 1, p. 6-13.

Fierstein, Judy, 2012, Katmai National Park volcanoes, in Volcanoes of Katmai and the Alaska Peninsula: Alaska Park Science, National Park Service, v. 11, no. 1, p. 14-21.

Fierstein, Judy, 2012, Concluding thoughts. Can another great volcanic eruption happen in Alaska?, in Volcanoes of Katmai and the Alaska Peninsula: Alaska Park Science, National Park Service, v. 11, no. 1, p. 88-93.

Gonnermann, H.M., Foster, J.H., Poland, Michael, Wolfe, C.J., Brooks, B.A., and Miklius, Asta, 2012, Coupling at Mauna Loa and Kîlauea by stress transfer in an asthenospheric melt layer: Nature Geoscience, v. 5, p. 826-829.

Haney, M.M., Mikesell, T.D., van Wijk, Kasper, and Nakahara, Hisashi, 2012, Extension of the spatial autocorrelation (SPAC) method to mixed-component correlations of surface waves: Geophysical Journal International, v. 191, p. 189-206.

Haney, M.M., Power, John, West, Michael, and Michaels, Paul, 2012, Causal instrument corrections for short-period and broadband seismometers: Seismological Research Letters, v. 83, p. 834-845.

Helz, R.T., 2012, Trace-element analyses of core samples from the 1967-1988 drillings of Kilauea Iki lava lake, Hawaii: U.S. Geological Survey Open-File Report 20121050, 46 p. [Available at http://pubs.usgs.gov/of/2012/1050.]

Hildreth, Wes, and Fierstein, Judy, 2012, Eruptive history of Mount Katmai, Alaska: Geosphere, v. 8, p. 1527-1567.

Hildreth, Wes, and Fierstein, Judy, 2012, The Novarupta-Katmai eruption of 1912 largest eruption of the twentieth century; centennial perspectives: U.S. Geological 
Survey Professional Paper 1791, 259 p. [Also available at http://pubs.usgs.gov/pp/1791/.]

Hildreth, Wes, Fierstein, Judy, and Calvert, A.T., 2012, Geologic map of Three Sisters volcanic cluster, Cascade Range, Oregon: U.S. Geological Survey Scientific Investigations Map 3186, 107 p., 2 sheets, scale 1:24,000. [Also available at http://pubs.usgs.gov/sim/3186/.]

Hill, D.P., 2012, Dynamic stresses, coulomb failure, and remote triggering — corrected: Bulletin of the Seismological Society of America, v. 102, p. 2313-2336.

Hill, D.P., 2012, Surface-wave potential for triggering tectonic (nonvolcanic) tremorcorrected: Bulletin of the Seismological Society of America, v. 102, p. 2337-2355.

Hill, D.P., 2012, Erratum to Dynamic stresses, coulomb failure, and remote triggering and to Surface-wave potential for triggering tectonic (nonvolcanic) tremor: Bulletin of the Seismological Society of America, v. 102, p. 2795.

Hoblitt, R.P., Orr, T.R., Heliker, Christina, Denlinger, R.P., Hon, Ken, and Cervelli, P.F., 2012, Inflation rates, rifts, and bands in a pāhoehoe sheet flow: Geosphere, v. 8, p. $179-195$.

Hurwitz, S., Harris, R.N., Werner, C.A., and Murphy, F., 2012, Heat flow in vapor dominated areas of the Yellowstone Plateau Volcanic Field-Implications for the thermal budget of the Yellowstone Caldera: Journal of Geophysical Research, v. 117, B10207, doi:10.1029/2012JB009463, 18 p.

Hurwitz, Shaul, Hunt, A.G., and Evans, W.C., 2012, Temporal variations of geyser water chemistry in the Upper Geyser Basin, Yellowstone National Park, USA: Geochemistry, Geophysics, and Geosystems, v. 13, Q12005, doi:10.1029/2012GC004388, $19 \mathrm{p}$.

Ingebritsen, S.E., 2012, Modeling the formation of porphyry-copper deposits: Science, v. 338 , no. 6114 , p. $1551-1552$.

Ingebritsen, S.E., and Appold, M.S., 2012, The physical hydrogeology of ore deposits: Economic Geology, v. 107, p. 559-584.

Jicha, B.R., Coombs, M.L., Calvert, A.T., and Singer, B.S., 2012, Geology and ${ }^{40} \mathrm{Ar} /{ }^{39} \mathrm{Ar}$ geochronology of the medium- to high-K Tanaga volcanic cluster, western Aleutians: Geological Society of America Bulletin, v. 124, p. 842-856.

Kauahikaua, Jim, and Poland, Mike, 2012, One hundred years of volcano monitoring in Hawaii: Eos Transactions American Geophysical Union, v. 93, no. 3, p. 29-30.

Kern, Christoph, Deutschmann, Tim, Werner, Cynthia, Sutton, A. J., Elias, Tamar, and Kelly, P.J., 2012, Improving the accuracy of $\mathrm{SO}_{2}$ column densities and emission rates obtained from upward-looking UV-spectroscopic measurements of volcanic plumes by taking realistic radiative transfer into account: Journal of Geophysical Research, v. 117, D20302, doi:10.1029/2012JD017936, 23 p.

Koleszar, A.M., Kent, A.J.R., Wallace, P.J., and Scott, W.E., 2012, Controls on longterm low explosivity at andesitic arc volcanoes-Insights from Mount Hood, Oregon: Journal of Volcanology and Geothermal Research, v. 219-220, p. 1-14.

Lipman, P.W., 2012, Geologic map of the Cochetopa Park and North Pass calderas, northeastern San Juan Mountains, Colorado: U.S. Geological Survey Scientific Investigations Map 3123, 48 p., 2 plates, scale 1:50,000, CD-ROM. [Also available at http://pubs.usgs.gov/sim/3123/.] 
Lowenstern, J.B., Bergfeld, D., Evans, W.C., and Hurwitz, S., 2012, Generation and evolution of hydrothermal fluids at Yellowstone-Insights from the Heart Lake Geyser Basin: Geochemistry, Geophysics, and Geosystems, v. 13, Q01017, doi:10.1029/2011GC003835, 20 p.

Lowenstern, J.B., Bleick, Heather, Vazquez, J.A., Castro, J.M., and Larson, P.B., 2012, Degassing of $\mathrm{Cl}, \mathrm{F}, \mathrm{Li}$, and Be during extrusion and crystallization of the rhyolite dome at Volcán Chaitén, Chile during 2008 and 2009: Bulletin of Volcanology, v. 74, p. 2303-2319.

Major, J.J., O’Connor, J.E., Podolak, C.J., Keith, M.K., Grant, G.E., Spicer, K.R., Pittman, Smokey, Bragg, H.M., Wallick, J.R., Tanner, D.Q., Rhode, Abagail, and Wilcock, P.R., 2012, Geomorphic response of the Sandy River, Oregon, to removal of Marmot Dam: U.S. Geological Survey Professional Paper 1792, 64 p., data tables. [Also available at http://pubs.usgs.gov/pp/1792/.]

Manga, Michael, Beresnev, Igor, Brodsky, E.E., Elkhoury, J.E., Elsworth, Derek, Ingebritsen, S.E., Mays, D.C., and Wang, Chi-Yuen, 2012, Changes in permeability caused by transient stresses-Field observations, experiments, and mechanisms: Reviews of Geophysics, v. 50, RG2004, doi:10.1029/2011RG000382, 24 p.

Masterlark, Timothy, Feigl, K.L., Haney, Matthew, Stone, Jonathan, Thurber, Clifford, and Ronchin, Erika, 2012, Nonlinear estimation of geometric parameters in FEMs of volcano deformation - Integrating tomography models and geodetic data for Okmok volcano, Alaska: Journal of Geophysical Research, v. 117, B02407, doi:10.1029/2011JB008811, 17 p.

Mather, T.A., Witt, M.L.I., Pyle, D.M., Quayle, B.M., Aiuppa, A., Bagnato, E., Martin, R.S., Sims, K.W.W., Edmonds, M., Sutton, A.J., and Ilyinskaya, E., 2012, Halogens and trace metal emissions from the ongoing 2008 summit eruption of Kîlauea volcano, Hawai' $i$ : Geochimica et Cosmochimica Acta, v. 83, p. 292-323.

McCleskey, R.B., Clor, L.E., Lowenstern, J.B., Evans, W.C., Nordstrom, D.K., Heasler, Henry, and Huebner, M.A., 2012, Solute and geothermal flux monitoring using electrical conductivity in the Madison, Firehole, and Gibbon Rivers, Yellowstone National Park: Applied Geochemistry, v. 27, p. 2370-2381.

McIntire, Jacqueline, Ramsey, D.W., Thoms, Evan, Waitt, R.B., and Begét, J.E., 2012, Database for volcanic processes and geology of Augustine Volcano, AlaskaDatabase for Professional Paper 1762: U.S. Geological Survey Data Series 677. [Available at http://pubs.usgs.gov/ds/677/.]

Moore, J.G., Gorden, M.A., and Sisson, T.W., 2012, Bedrock basins in the Sierra Nevada, Alta California: California Archaeology, v. 4, p. 99-122.

Nathenson, Manuel, 2012, Publications of the Volcano Hazards Program 2010: U.S. Geological Survey Open-File Report 2012-1177, 14 p. [Available at http://pubs.usgs.gov/of/2012/1177/.]

Nathenson, Manuel, Clynne, M.A, and Muffler, L.J.P., 2012, Eruption probabilities for the Lassen Volcanic Center and regional volcanism, northern California, and probabilities for large explosive eruptions in the Cascade Range: U.S. Geological Survey Scientific Investigations Report 2012-5176-B, 23 p. [Available at http://pubs.usgs.gov/sir/2012/5176/b/.]

O'Brien, J.F., Roman, D.C., Dixon, J.P., Power J.A., and Arnold, Richard, 2012, Multiple causes for non-eruptive seismic swarms at Mt. Martin, Katmai Volcanic Cluster, 
Alaska (2004-2008): Journal of Volcanology and Geothermal Research, v. 229-230, p. 13-22.

Orr, T.R., and Rea, J.C., 2012, Time-lapse camera observations of gas piston activity at $\mathrm{Pu}^{\prime} \mathrm{u}^{\prime} \overline{\mathrm{O}}^{`}{ }^{\circ}$, Kīlauea volcano, Hawai'i: Bulletin of Volcanology, v. 74, p. 2353-2362.

Parcheta, C.E., Houghton, B.F., and Swanson, D.A., 2012, Hawaiian fissure fountains 1- decoding deposits-episode 1 of the 1969-1974 Mauna Ulu eruption: Bulletin of Volcanology, v. 74, p. 1729-1743.

Patrick, M.R., and Orr, T.R., 2012, Rootless shield and perched lava pond collapses at Kîlauea Volcano, Hawai'i: Bulletin of Volcanology, v. 74, p. 67-78.

Pesicek, J.D., Sileny, J., Prejean, S.G., and Thurber, C.H., 2012, Determination and uncertainty of moment tensors for microearthquakes at Okmok Volcano, Alaska: Geophysical Journal International, v. 190, p. 1689-1709.

Poland, Mike, 2012, Conference report on the AGU Chapman Conference on Hawaiian Volcanoes-From Source to Surface: IAVCEI News, no. 4, p. 14-16.

Poland, M.P., Miklius, Asta, Sutton, A.J., and Thornber, C.R., 2012, A mantle-driven surge in magma supply to Kîlauea Volcano during 2003-2007: Nature Geoscience, v. 5, p. 295-300.

Prejean, Stephanie, Moran, Seth, and Power, John, 2012, Volcanic earthquakes in Alaska's National Parks, in Volcanoes of Katmai and the Alaska Peninsula: Alaska Park Science, National Park Service, v. 11, no. 1, p. 40-45.

Ramsey, M.S., Wessels, R.L., and Anderson, S.W., 2012, Surface textures and dynamics of the 2005 lava dome at Shiveluch volcano, Kamchatka: Geological Society of America Bulletin, v. 124, p. 678-689.

Reid, M.E., LaHusen, R.G., Baum, R.L., Kean, J.W., Schulz, W.H., and Highland, L.M., 2012, Real-time monitoring of landslides: U.S. Geological Survey Fact Sheet 20123008, 4 p. [Also available at http://pubs.usgs.gov/fs/2012/3008/.]

Robinson, J.E., 2012, High-resolution digital elevation dataset for Crater Lake National Park and vicinity, Oregon, based on LiDAR survey of August-September 2010 and bathymetric survey of July 2000: U. S. Geological Survey Data Series 716. [Available at http://pubs.usgs.gov/ds/716/.]

Robinson, J.E., Bacon, C.R., and Wayne, Chris, 2012, Under trees and water at Crater Lake National Park, Oregon: U.S. Geological Survey Scientific Investigations Map 3223, 1 plate. [Also available at http://pubs.usgs.gov/sim/3223/.]

Robinson, J.E., and Clynne, M.A., 2012, Lahar hazard zones for eruption-generated lahars in the Lassen Volcanic Center, California: U.S. Geological Survey Scientific Investigations Report 2012-5176-C, 13 p. [Available at http://pubs.usgs.gov/sir/2012/5176/c/.]

Robinson, J.E., Hildreth, Wes, Fierstein, Judy, and Calvert, A.T., 2012, Database for the geologic map of Three Sisters volcanic cluster, Cascade Range, Oregon, in Hildreth, Wes, Fierstein, Judy, and Calvert, A.T., Geologic map of Three Sisters volcanic cluster, Cascade Range, Oregon: U.S. Geological Survey Scientific Investigations Map 3186, 1 CD-ROM. [Also available at http://pubs.usgs.gov/sim/3186/.]

Robinson, J.E., and Lipman, P.W., 2012, Database for the geologic map of the Cochetopa Park and North Pass calderas, northeastern San Juan Mountains, Colorado, in Lipman, P.W., Geologic map of the Cochetopa Park and North Pass calderas, northeastern San Juan Mountains, Colorado: U.S. Geological Survey Scientific 
Investigations Map 3123, scale 1:50,000, CD-ROM. [Also available at http://pubs.usgs.gov/sim/3123/.]

Rudolph, M.L., Manga, M., Hurwitz, S., Johnston, M., Karlstrom, L., and Wang, C.-Y., 2012, Mechanics of Old Faithful Geyser, Calistoga, California: Geophysical Research Letters, v. 39, L24308, doi:10.1029/2012GL054012, 5 p.

Ruprecht, Philipp, Bergantz, G.W., Cooper, K.M., and Hildreth, Wes, 2012, The crustal magma storage system of Volcán Quizapu, Chile, and the effects of magma mixing on magma diversity: Journal of Petrology, v. 53, p. 801-840.

Saffaraval, Farhad, Solovitz, S.A., Ogden, D.E., and Mastin, L.G., 2012, Impact of reduced near-field entrainment of overpressured volcanic jets on plume development: Journal of Geophysical Research, v. 117, B05209, doi:10.1029/2011JB008862, 13 p.

Schaefer, J.R., ed., 2012, The 2009 eruption of Redoubt Volcano, Alaska, with contributions by Bull, Katherine, Cameron, Cheryl, Coombs, Michelle, Diefenbach, Angie, Lopez, Taryn, McNutt, Steve, Neal, Christina, Payne, Allison, Power, John, Schneider, Dave, Scott, William, Snedigar, Seth, Thompson, Glenn, Wallace, Kristi, Waythomas, Chris, Webley, Peter, and Werner, Cynthia: Alaska Division of Geological \& Geophysical Surveys Report of Investigation 2011-5, 45 p. [Available at http://www.dggs.alaska.gov/pubs/id/23123.]

Schaefer, J.R., and Wallace, K.L., 2012, Ash fall contour map of the 2009 eruption of Redoubt Volcano, Alaska-Digital shapefiles of contours and sample locations: Alaska Division of Geological and Geophysical Surveys Miscellaneous Publication 143, DVD. [Available at http://www.dggs.alaska.gov/pubs/id/23463.]

Schmitt, D.R., Liberty, L.M., Kessler, J.E., Kuck, Jochem, Kofman, Randolph, Bishop, Ross, Shervais, J.W., Evans, J.P., and Champion, D.E., 2012, The ICDP Snake River geothermal drilling project-Preliminary overview of borehole geophysics:

Geothermal Resources Council Transactions, v. 36, p. 1017-1022.

Schwaiger, H.F., Denlinger, R.P., and Mastin, L.G., 2012, Ash3d: A finite-volume, conservative numerical model for ash transport and tephra deposition: Journal of Geophysical Research, v. 117, B04204, doi:10.1029/2011JB008968, 20 p.

Sherrod, D.R., Champion, D.E., and McGeehin, J.P., 2012, Age and duration of volcanic activity at Diamond Craters, southeastern Oregon: Journal of Volcanology and Geothermal Research, v. 247-248, p. 108-114.

Steiner, A.R., Browne, B.L., and Nye, C.J., 2012, Quenched mafic inclusions in $\leq 2200$ years B.P. deposits at Augustine Volcano, Alaska: International Geology Review, v. 54, p. 1241-1270.

Stovall, W.K., Houghton, B.F., Hammer, J.E., Fagents, S.A., and Swanson, D.A., 2012, Vesiculation of high fountaining Hawaiian eruptions-Episodes 15 and 16 of 1959 Kīlauea Iki: Bulletin of Volcanology, v. 74, p. 441-455.

Swanson, D.A., Rose, T.R., Fiske, R.S., and McGeehin, J.P., 2012, Keanakāko'i Tephra produced by 300 years of explosive eruptions following collapse of Kīlauea's caldera in about 1500 CE: Journal of Volcanology and Geothermal Research, v. 215-216, p. $8-25$.

Swanson, D.A., Zolkos, S.P., and Haravitch, Ben, 2012, Ballistic blocks around Kīlauea Caldera-Their vent locations and number of eruptions in the late 18th century: Journal of Volcanology and Geothermal Research, v. 231-232, p. 1-11. 
Thurber, Clifford, Murphy, Rachel, Prejean, Stephanie, Haney, Matthew, Bennington, Ninfa, Powell, Lee, and Paskievitch, John, 2012, Earthquake studies reveal the magmatic plumbing system of the Katmai volcanoes, in Volcanoes of Katmai and the Alaska Peninsula: Alaska Park Science, National Park Service, v. 11, no. 1, p. 34-39.

Tilling, R.I., 2012, Foreword, in Hildreth, Wes, and Fierstein, Judy, The NovaruptaKatmai eruption of 1912-largest eruption of the twentieth century; centennial perspectives: U.S. Geological Survey Professional Paper 1791, p. iii-iv. [Also available at http://pubs.usgs.gov/pp/1791/.]

Tilling, R.I., 2012, Lava: Singapore, McGraw-Hill Encyclopedia of Science \& Technology, 11th ed., v. 9, p. 732-733.

Tilling, R.I., 2012, Pyroclast: Singapore, McGraw-Hill Encyclopedia of Science \& Technology, 11th ed., v. 14, p. 623-624.

Tilling, R.I., 2012, Pyroclastic rocks: Singapore, McGraw-Hill Encyclopedia of Science \& Technology, 11th ed., v. 14, p. 624-629.

Tilling, R.I., 2012, Tuff: Singapore, McGraw-Hill Encyclopedia of Science \& Technology, 11th ed., v. 18, p. 713-714.

Tilling, R.I., 2012, Volcano: Singapore, McGraw-Hill Encyclopedia of Science \& Technology, 11th ed., v. 19, p. 373-384.

Tilling, R.I., 2012, Volcanology: Singapore, McGraw-Hill Encyclopedia of Science \& Technology, 11th ed., v. 14, p. 384-395.

Trusdell, F.A., 2012, Mauna Loa-History, hazards, and risk of living with the world's largest volcano: U.S. Geological Survey Fact Sheet 2012-3104, 4 p. [Also available at http://pubs.usgs.gov/fs/2012/3104/.]

Trusdell, F.A., Chadderton, A., Hinchliffe, G., Hara, A., Patenge, B., and Weber, T., 2012, Tohoku-Oki earthquake tsunami runup and inundation data for sites around the Island of Hawai'i: U.S. Geological Survey Open-File Report 2012-1229, 36 p. [Available at http://pubs.usgs.gov/of/2012/1229/.]

Underwood, S.J., Feeley, T.C., and Clynne, M.A., 2012, Hydrogen isotope investigation of amphibole and biotite phenocrysts in silicic magmas erupted at Lassen Volcanic Center, California: Journal of Volcanology and Geothermal Research, v. 227-228, p. 32-49.

Van Manen, S.M., Blake, S., and Dehn, J., 2012, Satellite thermal infrared data of Shiveluch, Kliuchevskoi and Karymsky, 1993-2008-Effusion, explosions and the potential to forecast ash plumes: Bulletin of Volcanology, v. 74, p. 1313-1335.

Vaughan, R.G., Keszthelyi, L.P., Lowenstern, J.B., Jaworowski, Cheryl, and Heasler, Henry, 2012, Use of ASTER and MODIS thermal infrared data to quantify heat flow and hydrothermal change at Yellowstone National Park: Journal of Volcanology and Geothermal Research, v. 233-234, p. 72-89.

Vaughan, R.G., Lowenstern, J.B., Keszthelyi, L.P., Jaworowski, Cheryl, and Heasler, Henry, 2012, Mapping temperature and radiant geothermal heat flux anomalies in the Yellowstone geothermal system using ASTER thermal infrared data: Geothermal Resources Council Transactions, v. 36, p. 1403-1409.

Vazquez, J.A., and Lidzbarski, M.I., 2012, High-resolution tephrochronology of the Wilson Creek Formation (Mono Lake, California) and Laschamp event using ${ }^{238} \mathrm{U}_{-}$ ${ }^{230}$ Th SIMS dating of accessory mineral rims: Earth and Planetary Science Letters, v. $357-358$, p. 54-67. 
Washington Military Department, Emergency Management Division, 2012, Mount Baker/Glacier Peak coordination plan: Washington Military Department, Emergency Management Division, 39 p., accessed November 12, 2012, at http://www.emd.wa.gov/plans/plans_index.shtml.

Waythomas, C.F., Pierson, T.C., Major, J.J., and Scott, W.E., 2012, Preliminary observations of voluminous ice-rich and water-rich lahars generated during the 2009 eruption of Redoubt, Alaska: U.S. Geological Survey Open-File Report 2012-1078, 42 p. [Available at http://pubs.usgs.gov/of/2012/1078/.]

Werner, Cynthia, Evans, W.C., Kelly, P.J., McGimsey, Robert, Pfeffer, Melissa, Doukas, Michael, and Neal, Christina, 2012, Deep magmatic degassing versus scrubbingElevated $\mathrm{CO}_{2}$ emissions and $\mathrm{C} / \mathrm{S}$ in the lead-up to the 2009 eruption of Redoubt Volcano, Alaska: Geochemistry, Geophysics, and Geosystems, v. 13, Q03015, doi:10.1029/2011GC003794, $18 \mathrm{p}$.

Wright, H.M., Bacon, C.R., Vazquez, J.A., and Sisson, T.W., 2012, Sixty thousand years of magmatic volatile history before the caldera-forming eruption of Mount Mazama, Crater Lake, Oregon: Contributions to Mineralogy and Petrology, v. 164, p. $1027-$ 1052.

Wright, H.M.N., Cashman, K.V., Mothes, P.A., Hall, M.L., Ruiz, A.G., and Le Pennec, Jean-Luc, 2012, Estimating rates of decompression from textures of erupted ash particles produced by 1999-2006 eruptions of Tungurahua volcano, Ecuador: Geology, v. 40, p. 619-622. 